\title{
Analyzing double degrees in Spain: A proposal
}

\author{
Norat Roig-Tierno*, Alicia Mas-Tur**, Belén Ribeiro-Navarrete** \\ *Universitat Politècnica de València \\ **Universitat de València
}

\begin{abstract}
This article reviews the situation of single and double degrees in both public and private Spanish universities. To do so, this study analyzes information from the Registry of Universities, Centers, and Qualifications (RUCT) and Universia Spain. After analyzing the programs currently available to students, we present a proposal to establish a double degree in Administration and Business Management/Industrial Management Engineering. The proposal specifies the degree's main objectives, specific nature, and fundamental aims and benefits in terms of technical, corporate, innovative, and entrepreneurial competencies.
\end{abstract}

Keywords: Double degree, Administration and Business Management, Industrial Management Engineering

\section{Introduction}

This study presents a proposal to create a double degree in Administration and Business Management/Industrial Management Engineering. This degree would cover the full range of industry needs in the following knowledge areas: production process management, resource management, quality management, innovation management, internationalization strategies, and other aspects including accounting, marketing, and entrepreneurship.

To support the proposal, this study analyzes existing double degrees in Spain. According to Universia Spain, two types of university qualifications exist in Spain: official university qualifications and qualifications granted by specific universities. This study focuses only on official university titles. Spanish universities offer 3,160 undergraduate degrees, 8,235 postgraduate degrees, and 1,574 $\mathrm{PhD}$ programs. Of these 3,160 undergraduate degrees, 441 are double degrees. This study analyzes these 441 double degrees to discover whether a double degree in Administration and Business Management/Industrial Management Engineering is viable.

Section 2 outlines the university degrees currently available in Spain. Section 3 describes the double degree proposal. Finally, section 4 presents conclusions and future research opportunities.

\section{University degrees}

The Registry of Universities, Centers, and Qualifications (RUCT) provides relevant information about universities, centers, and qualifications in the Spanish university system, including the new official degrees (grados in Spanish), master's degrees, and PhD programs. The RUCT institution is a public and administrative tool that is constantly updating the information it offers.

According to Universia Spain, there are currently 50 public universities and 32 private universities in Spain. Furthermore, Spanish degrees may be official national degrees (títulos oficiales) or degrees granted only by a particular university (títulos propios). All universities, regardless of whether they are public or private, can issue both qualifications. 
Official degrees (grados, master's degrees, and PhDs), which are valid throughout Spain, appear in the RUCT and meet the requirements established by the European Higher Education Area (EHEA). Therefore, these degrees are valid in all countries within the EHEA. These degrees are also equivalent to degrees granted in other countries outside the EHEA.

An individual university's degrees have several labels: non-official degree, non-official master's degree, Master's for Specialists, or Master's for Experts, among others. Unofficial qualifications are created by universities and are not valid within the EHEA. Generally, unofficial qualifications are not equivalent to degrees in other countries and are recognized only by the university that offers them.

This study focuses on official degrees. In Spain, there are currently 3,160 undergraduate degrees (441 of which are double degrees), 8,235 postgraduate degrees, and 1,574 $\mathrm{PhD}$ programs. General degrees consist of 240 European Credit Transfer and Accumulation System (ECTS) credits (including a final degree dissertation), whereas double degrees consist of 360 ECTS credits. The Spanish provinces with the highest numbers of double degrees are Madrid (211), Valencia (45), Barcelona (40), and Seville (27). All other provinces offer fewer than 15 double degrees each. Table 1 lists Spanish universities and the single degrees and double degrees on offer.

Table 1. BA degrees and double degrees at Spanish universities (Source: RUCT and Universia)

\begin{tabular}{|c|c|c|c|}
\hline University & $\begin{array}{c}\text { All degrees } \\
\text { (RUCT) }\end{array}$ & $\begin{array}{l}\text { All degrees } \\
\text { (Universia) }\end{array}$ & $\begin{array}{c}\text { Double } \\
\text { degrees }\end{array}$ \\
\hline Universidad Europea de Madrid & 46 & 53 & 49 \\
\hline Universidad Rey Juan Carlos & 55 & 55 & 42 \\
\hline Universidad San Pablo-CEU & 32 & 35 & 28 \\
\hline Universidad Cardenal Herrera-CEU & 20 & 21 & 26 \\
\hline Universidad Antonio de Nebrija & 30 & 26 & 23 \\
\hline Universidad Camilo José Cela & 33 & 38 & 19 \\
\hline Universidad de Sevilla & 62 & 67 & 18 \\
\hline Universidad Alfonso X El Sabio & 42 & 33 & 16 \\
\hline Universidad Autónoma de Barcelona & 79 & 87 & 12 \\
\hline Universidad Católica de Valencia San Vicente Mártir & 24 & 25 & 12 \\
\hline Universidad de Cádiz & 42 & 49 & 12 \\
\hline Universidad de Navarra & 34 & 43 & 12 \\
\hline Universidad Europea Miguel de Cervantes & 12 & 12 & 10 \\
\hline Universidad Católica San Antonio de Murcia & 29 & 30 & 9 \\
\hline Universidad Francisco de Vitoria & 21 & 18 & 9 \\
\hline Universidad Pablo de Olavide & 20 & 19 & 9 \\
\hline Universidad Pontificia Comillas & 18 & 15 & 8 \\
\hline Universitat de València (Estudi General) & 53 & 57 & 8 \\
\hline Universidad Carlos III de Madrid & 27 & 28 & 7 \\
\hline Universidad Católica Santa Teresa de Jesús de Ávila & 10 & 11 & 7 \\
\hline Universidad de Deusto & 21 & 27 & 7 \\
\hline Universidad Complutense de Madrid & 69 & 85 & 6 \\
\hline Universidad de Barcelona & 63 & 67 & 6 \\
\hline Universidad de Girona & 41 & 46 & 6 \\
\hline Universidad de Huelva & 29 & 28 & 6 \\
\hline Universidad Ramón Llull & 34 & 34 & 6 \\
\hline UniversitatAbatOliba CEU & 11 & 12 & 6 \\
\hline Universitat Internacional de Catalunya & 14 & 14 & 6 \\
\hline Universidad de Extremadura & 59 & 64 & 5 \\
\hline Universidad de Málaga & 52 & 58 & 5 \\
\hline Universidad de Granada & 62 & 78 & 4 \\
\hline Universidad de Lleida & 31 & 31 & 4 \\
\hline Universidad Autónoma de Madrid & 40 & 41 & 3 \\
\hline
\end{tabular}




\begin{tabular}{|l|c|c|c|}
\hline Universidad de Burgos & 27 & 27 & 3 \\
\hline Universidad de Las Palmas de Gran Canaria & 36 & 32 & 3 \\
\hline Universidad Pompeu Fabra & 29 & 34 & 3 \\
\hline Universidad de Alcalá & 36 & 34 & 2 \\
\hline Universidad de Alicante & 37 & 37 & 2 \\
\hline Universidad de Córdoba & 32 & 29 & 2 \\
\hline Universidad de Oviedo & 49 & 55 & 2 \\
\hline Universidad de Valladolid & 56 & 71 & 2 \\
\hline Universidad del País Vasco/EuskalHerrikoUnibertsitatea & 69 & 73 & 2 \\
\hline Universidad Pública de Navarra & 19 & 21 & 2 \\
\hline Universidad San Jorge & 14 & 13 & 2 \\
\hline Universitat de les Illes Balears & 32 & 30 & 2 \\
\hline Universitat Politècnica de València & 30 & 30 & 2 \\
\hline IE Universidad & 10 & 7 & 1 \\
\hline Universidad de A Coruña & 37 & 40 & 1 \\
\hline Universidad de Jaén & 33 & 38 & 1 \\
\hline Universidad de Zaragoza & 54 & 55 & 1 \\
\hline Universidad Politécnica de Catalunya & 43 & 44 & 1 \\
\hline Universidad Rovira i Virgili & 39 & 39 & 1 \\
\hline Mondragón Unibertsitatea & 15 & 15 & 0 \\
\hline Universidad a Distancia de Madrid & 23 & 15 & 0 \\
\hline Universidad de Almería & 29 & 27 & 0 \\
\hline Universidad de Cantabria & 29 & 27 & 0 \\
\hline Universidad de Castilla-La Mancha & 46 & 64 & 0 \\
\hline Universidad de La Laguna & 45 & 50 & 0 \\
\hline Universidad de La Rioja & 19 & 19 & 0 \\
\hline Universidad de León & 37 & 37 & 0 \\
\hline Universidad de Murcia & 48 & 50 & 0 \\
\hline Universidad de Salamanca & 64 & 74 & 0 \\
\hline Universidad de Santiago de Compostela & 44 & 48 & 0 \\
\hline Universidad de Vic-Universidad Central de Catalunya & 26 & 29 & 0 \\
\hline Universidad de Vigo & 40 & 41 & 0 \\
\hline Universidad Internacional de La Rioja & 17 & 14 & 0 \\
\hline Universidad Politécnica de Madrid & 40 & 42 & 0 \\
\hline Universidad Pontificia de Salamanca & 22 & 22 & 0 \\
\hline UniversitatOberta de Catalunya & 15 & 17 & 0 \\
\hline Universidad Jaume I de Castellón & 31 & 32 & 0 \\
\hline Universidad Miguel Hernández de Elche & 27 & 25 & 0 \\
\hline Universidad Nacional de Educación a Distancia & 27 & 27 & 0 \\
\hline Universidad Politécnica de Cartagena & 18 & 20 & 0 \\
\hline Universidad Europea de Canarias & 5 & -- & -- \\
\hline Universidad Europea de Valencia & 10 & -- & -- \\
\hline Universidad Internacional Isabel I de Castilla & 10 & -- & -- \\
\hline Universidad Loyola Andalucía & 11 & -- & -- \\
\hline Universitat Internacional Valenciana & 5 & -- & -- \\
\hline Total & & & $\mathbf{4 4 1 8}$ \\
\hline
\end{tabular}

Of the 441 double degrees, 108 are in Administration and Business Management, 88 are in Law, 69 are in Communication Sciences, and 49 are in Technology and Engineering. Spanish universities also offer double degrees in other subjects like Teaching, Political Sciences, Marketing and Advertising, and Computing.

Nevertheless, only 53 double degrees are registered in the RUCT. This number is low because double degrees are actually two complete degrees and therefore ultimately provide the student with two different qualifications rather than one (double) degree. This is the case for most double degrees. For example, a student taking the double degree in Administration and Business Management/Law at the University of Valencia would obtain two qualifications upon completing the degree: one qualification as a graduate in Administration and Business Management and another as a graduate in Law. The 
University of Valencia's webpage describes this particular degree's structure as follows: 'These studies are planned so that the student may obtain a degree in Administration and Business Management ( $A D E$ in Spanish) and a degree in Law after studying for a period of five academic years'.

In this study, we make no distinction whatsoever because we understand that the two ways of obtaining the double degree are equally valid and provide students with the necessary knowledge in both fields.

\section{New double degree proposal}

After performing the above analysis, we propose the creation of a double degree in Administration and Business Management/Industrial Management Engineering.

The double degree Administration and Business Management/Industrial Management Engineering would cover industrial environment's needs through the following knowledge fields: production process management, resource management, quality management, innovation management, internationalization strategies, and other aspects that include accounting, marketing, and entrepreneurship. This approach means this degree would provide students with the knowledge and tools required to adapt to the changing industrial environment, while adding value by combining competencies from different technical, business, and international fields.

The education/training of students enrolled in this double degree responds to the increasing demand for versatile professionals in small and medium enterprises (SME), large enterprises, and enterprises with a technological basis because of the double degree's technical, managerial, and international components (Asgary \& Robbert, 2010). Hence, students of the double degree in Administration and Business Management/Industrial Management Engineering would be trained to perform a range of tasks such as strategic decision-making, innovation management for competitive advantage, optimization and management of limited resources, and planning, development, and implementation of expansion and internationalization strategies.

Thus, the double degree proposed in this study has two objectives: (1) to train versatile professionals with strong scientific and technical skills together with a solid theoretical grounding in industrial management engineering; and (2) to train professional graduates in business management using a practical approach based on models, case studies, and experiences.

The main objectives and benefits of this double degree are technical, business, and innovative and entrepreneurial competencies. Technical competencies are attained by (1) acquiring knowledge related to industrial management based not only on advanced textbooks but also on avant-garde business; and (2) understanding and mastering the basic concepts and techniques of different scientific and technological fields such as thermodynamics, electricity, design, materials, electromagnetism, chemistry, acoustics, environment, and quality.

Business-related competencies refer to the following areas. (1) Building knowledge of existing business structures and their evolution and developing capabilities in business management for decision-making. (2) Compiling, selecting, and interpreting relevant information to analyze and judge relevant social, scientific, and ethical topics. Students would also learn to communicate and transmit information and ideas, solve problems, analyze data, and find solutions. (3) Acquiring resources and abilities to provide 
enterprises with differentiating characteristics (e.g., developing databases to manage and use ICTs, developing tools to manage resources related to the control, implementation, and design of processes, developing the ability to implement management and quality control systems, and defining follow-up and monitoring mechanisms through evaluation processes.

Innovation and entrepreneurial competencies refer to students' training with an international, entrepreneurial, and innovative orientation to generate sustainable competitive advantage.

The double degree in Administration and Business Management/Industrial Management Engineering is aimed at all kinds of students who want to build a career working in organizations and enterprises by combining strong technical competencies with an innovative and international approach. This degree is also aimed at managers and professionals keen to reinforce their knowledge and skills in managing available resources to obtain competitive advantage, while deepening their knowledge of industrial management.

\section{Conclusions and future research}

This study proposes the creation of a new qualification: a double degree in Administration and Business Management/Industrial Management Engineering. Similar double degrees are Electrical Engineering/Establishment and Operation of Companies at the Universidad Europea de Madrid; Industrial Technology Engineering/Administration and Business Management at the Universitat de Girona and the Universidad de Deusto; Computer Engineering/Administration and Business Management at the Universidad Rey Juan Carlos and the Universidad de Las Palmas de Gran Canaria; and Industrial Electronics Engineering and Automation/Establishment and Operation of Companies at the Universidad Europea de Madrid.

These double degrees include modules related to Administration and Business Management. However, they do not allow students to combine Administration and Business Management with Industrial Management Engineering, which is a key degree to link technological knowledge, society's needs, and business management. So far, no university offers the double degree this study proposes. Nonetheless, industry and the economy have two main features that call for such a degree: the need to optimize companies' resources management; and the increasing competition and complexity of national markets, which forces firms to internationalize. Thus, this study proposes the creation of a double degree that will educate and train versatile professionals with strong scientific and technical skills together with a solid theoretical grounding in industrial management engineering. Graduates will gain insight and competencies in administration and business management through a practical approach based on models, case studies, and experience. Furthermore, the degree can offer an international approach that will allow graduates to develop their abilities in a globalized context (Culver, Puri, Spinelli, DePauw \& Dooley, 2011).

Future research could design a triple degree in Administration and Business Management and Industrial Management Engineering. According to Universia, only two triple degrees exist in Spain: the triple degree in Journalism/Audiovisual Communication and Multimedia/Advertising and the triple degree in Media and Performing Arts/Musical Creation/Dance Sciences, both at the Universidad Europea de Madrid. 


\section{References}

Asgary, N., \& Robbert, M. A. (2010). A cost-benefit analysis of an international dual degree programme. Journal of Higher Education Policy and Management, 32(3), 317-325.

Datos Básicos del Sistema Universitario Español (2014). Ministerio de Educación Cultura y deporte.

Farrior, S., \& Davis, L. (2012). Eligibility and Academic Requirements for Participation in International Dual Degree Programs.

Culver, S. M., Puri, I. K., Spinelli, G., DePauw, K. P., \& Dooley, J. E. (2011). Collaborative dual-degree programs and value added for students: Lessons learned through the EVALUATE-E project. Journal of Studies in International Education, 1028315311403934.

RUCT - Registro de Universidades, Centros y Títulos. Recuperado el 28 de enero de 2015, de https://www.educacion.gob.es/ruct/home

UNIVERSIA. Last consulted 25/01/2015 de http://www.universia.es/ 